Bull. Fac. Agric., Cairo Univ., 69: 189-199 (2018).

\title{
EVALUATION AND SELECTION OF NEW LINES OF BARHI DATE PALM SEEDS OUTPUT UNDER ALEXANDRIA GOVERNORATE CONDITIONS 3- CHARACTERIZATION OF TEN FEMALE DATE PALM GENOTYPES
}

(Received: 16.8.2018)

\author{
By \\ H. A. El-Ashry \\ Breeding Research Department for fruit Tree, Ornamental and Woody Plants, \\ Horticulture Research Institute, Agricultural Research Center, Alexandria, Egypt.
}

\begin{abstract}
The present investigation was carried out through 2015 and 2016 in El-Sabahia Experimental Station, Alexandria Governorate, Agricultural Research Center. Ten different date palm seeded females trees were chosen to identify the superior trees with respect to yield and fruit quality, under Alexandria Governorate conditions. Three seeded palm trees (No. 3, 5 and 9) were superior in their yield, comparing with Barhi cultivar. Also, two seeded palm trees (No. 3 and 9) were superior in their weight and shape of fruits and flesh percentage. Chemical contents, i,e T.S.S, total sugars, reducing and nonreducing sugar and tannins were studied. There were four trees (No. 1, 5, 8 and 9) were superior in fruit chemical properties comparing with Barhi cultivar (control). The results of molecular analysis of genomic DNA for the ten different seeded female date palm using ISSR markers showed that the total number of amplicons amplified by the ten primers was 207 with an average of 20.7/primer. The polymorphism ranged from 76.9 to $100 \%$. with an average of $88.42 \%$. Two primers represent $100 \%$ polymorphic amplicons (No. 4 and No. 9), (primers No.7 and No.2) recorded the highest percentage of polymorphism (94.4 and 92.9\%) respectively. Genetic similarity value was very low among the ten tested palm trees, ranging from $11.0 \%$ to $64.1 \%$. The lowest percentage was recorded between tree No 7 and No. 9, where as the highest percentage was recorded between Tree No. 9 and Tree No.1. This low similarity value may be attributed to its origin as seeds. This polymorphism renders these markers useful for further genetic studies in date palm.
\end{abstract}

Key words : Phoenix dactylifera L., female types, fruit quality, Barhi cv.

\section{INTRODUCTION}

Date palm (Phoenix dactylifera $\mathrm{L}$.) is one of the most important fruit trees in Egypt. This tree is the major, and widely grown fruit tree in the middle east. "Barhi", the most popular cultivar worldwide, is marketed and consumed at the full mature stage of development. For successful improvement program of date palm, there is a need to evaluate the seeded date palm trees of Barhi, already grown in El-Sabahia Experimental Station, Alexandria Governorate, Egypt.

Ten seeded Barhi female palm trees were selected and compared with Barhi cultivar, to evaluate the superior line for fruit quality and yield. Rokba et al.(1990) evaluated some of the unknown seeded date palm trees grown in a wide population. Al-Rawahi et al. (2005) studied the chemical composition of date variables due to various factors such as cultivar, climate, amount of fertilization and type of cultural practices. Also, Al-Redhaiman (2005) studied the chemical changes during storage of Barhi date fruits under controlled atmosphere conditions. Al-Hamoudi et al., (2006) identified the suitable pollinator for Barhi date palm cultivar under the conditions of Fayoum Governorate. Metwaly et al. (2009) reported six semi-dry seeded date palms, which were found to be superior in yield and fruit qualities than Sewi cv. Also, they indicated four soft date palm superior in yield and fruit qualities than Zaghloul cv. Physical and chemical characteristics of date palm fruits were studied by Ismail et al. (2008), Rizk et al. (2007) and Mohamed et al. (2004).

Al-Juhaim et al.(2012) studied the physical and chemical properties of seven different date fruits in Saudi Arabia. El-Merghany and Zaen El-Dean(2013) evaluated and classified some 
date palm cultivars grown under Toshky conditions into two groups, namely dry date palms (Sakkoty, Bartamoda, Gondela, Molkaby and Balady) and soft date palms (Barh and Sokkary).

Molecular markers such as AFLP , RAPD and ISSR were reported by several groups. Although Ameer et al., (2016), Jbir et al., (2006) and Zamani et al., (2007) concluded that pomegranate is highly polymorphic. Others concluded that the degree of polymorphism was surprisingly low, (Aradhya, 2006 and Yilmaz et al., 2006). Some studies found that the apparent phenotypical differences among some cultivars were not reflected in the polymorphism of the molecular markers. Obviously, many more markers should be isolated from cultivars to enhance breeding and evolutionary studies.

The selection of superior palms from the female seeded palm trees of Barhi is the aim of the current study, through studying fruit physical properties and chemical contents of date fruits for certain promising lines, under Alexandria Governorate conditions. Also to evaluate the degree of polymorphism to distinguish between the ten female seeded palm trees at the molecular level.

\section{MATERIALS AND METHODS}

\subsection{Horticultural studies}

\subsubsection{Flowering and fruit set}

This investigation was conducted through two seasons (2015 and 2016), in El-Sabahia Experimental Station, Alexandria Governorate, to evaluate ten female date palm seedling trees (Barhi). These seedling trees are ten year old planted at $7 \times 10 \mathrm{~m}$ apart, healthy and received regularly the normal horticultural practices. The chosen female palm seedling trees were hand pollinated using pollen grains of one male date palm in the same area. The strands of each spathe were detached and female spathes on each palm tree under study were pollinated directly, once after spath, and cracking. Each female spath was pollinated with an equal amount of male strands (6-7 strands), then the distal end of the spathe was tied.

After pollination, the female spathes were covered with perforated paper bags to prevent any cross contamination with foreign pollen grains, and were carefully tied around the end of the spathe. Then, the bags were shaken gently to insure the spread of pollen grains among female flowers. After ten days, the bags were removed, then the number of flowers and fruit setting on ten strands per spathe were recorded after June fall, to determine fruit set percentage.

All bunches were harvested at the full color (the end of September). Three samples as replications (3 spathes) from each female seedling tree under study were picked at random. Each fruit sample contained 25 fruits for determination of physical and chemical fruit properties as outlined in the methods of A.O.A.C. (1995).

\subsubsection{Physical properties of the fruits}

The morphological characters of the fruits of ten female types were measured, i.e. fruit weight, fruit size, fruit length and diameter, flesh weight and flesh percentage.

\subsubsection{Chemical properties of the fruits}

Values of total soluble solids (T.S.S.) content were determined in fruit Juice using a hand refractomater (A.O.A.C.1995). In addition, reducing and total sugar percentages were determined in Juice according to the method of Lane and Eynon as described by the A.O.A.C., (1995). The non-reducing sugars were calculated from the difference between total and reducing sugars. Tannin content was determined by using standard curve of tannic acid and expressed as mg tannins percent g.f wt. fruit peel and described by Resenabatt and Pluso (1941). Chlorophyll $(a+b)$ of the fruit skin were determined according to the procedure suggested by Wensttein, (1957).

\subsection{DNA Finger prints}

\subsubsection{Inter Simple Sequence Repeats (ISSRs)}

Total DNA was extracted from young leaves as described by Porebski et al., (1997). Ten ISSR primers were used for PCR amplification (Table 1) PCR amplifications were performed in a Perkin-Elmer/Gene Amp R PCR system 9700 (PE. Applied Biosystems) programmed to fulfill 40 cycles after an initial denaturation step at $94^{\circ} \mathrm{C}$ for I min, an annealing step at $36^{\circ} \mathrm{C}$ for 1 $\mathrm{min}$, and an elongation step at $72^{\circ} \mathrm{C}$ for $1.5 \mathrm{~min}$.

Table (1): Sequences of reliable ISSR primers.

\begin{tabular}{|c|c|}
\hline Primers & Sequence \\
\hline IS 1 & TAT $(\text { CA })_{7}$ \\
\hline IS 2 & CAC $(\text { TCC })_{5}$ \\
\hline IS 3 & TTT $(\text { TCC })_{5}$ \\
\hline IS 6 & $(\text { GA })_{8}$ CG \\
\hline IS 7 & ATTA $(\text { CA })_{7}$ \\
\hline IS 8 & $(\text { AG })_{8}$ CT \\
\hline IS 9 & AAC $(\text { TG })_{7}$ T \\
\hline IS 10 & $(\text { TCC })_{5}$ AC \\
\hline A 9 & $(\text { AGC })_{4}$ AC \\
\hline A 12 & $(\text { Acc })_{5}$ TC \\
\hline
\end{tabular}


The primer extension was extended to $7 \mathrm{~min}$ at $72{ }^{\circ} \mathrm{C}$ in the final cycle.

The amplification products were resolved by electrophoresis in a $1.5 \%$ agarose gel containing ethidium bromide $(0.5 \mathrm{ug} / \mathrm{ml})$ in IXTBE buffer at 95 volts. PCR products were visualized under UV light and photographed using a Polaroid camera. Amplified products were visually examined and the presence or absence of each band was scroed as I or O, respectively.

\subsubsection{Data analysis, DNA fingerprint}

A similarity matrix using the similarity coefficients of Nei and $\mathrm{Li}$ (1979), was constructed for ISSR data based on the presence (coded as 1) or absence (coded as $\mathrm{O}$ ) of the resulted fragments for each primer. Moreover, the relationships among the different female palm trees as revealed by dendrogram were done using SPSS windows program (V.10)

\subsubsection{Statistical analysis.}

The experiment included in this study followed a complete randomized design in a factorial experiment. The obtained data were subjected to analysis of variance (ANOVA) according to Snedecor and Cochran (1980). Means were differentiated by Duncan's multiple range test at 5\% level (Duncan, 1955).

\subsection{Horticultural studies \\ 3.1.1. Flowering, fruit set and yield}

The data presented in Table (2) show the dates of the first and last spathe of ten different female types and Barhi cultivar in the two seasons under study (2015 and 2016). The longest flowering period was for the tenth tree (27 days) in the first season, and for the ninth tree (31 days) in the second season. The shortest period was for the fifth tree (13 and 14 days) in the two seasons, respectively. As for the number of spathes per tree, the results indicated that the third tree had 22 spathes while the lowest number 14 was for the fourth tree, in 2015. In 2016 the third and fifth trees had 22 spathes and the lowest number was 14 for tree No. 8 .

The results in Table (2) show that fruit set percentage of the ten female types under study varied considerably. The fifth and ninth trees gave the highest percentage of fruit set (70.16 and $70.60 \%$ ), the lowest percentage was for the third tree $(52.38 \%)$ in the first season. In the second season, the seventh and ninth trees had the percentage (56.39 and 58.13\%), respectively, and the lowest was for the sixth tree $(52.12 \%)$.

The highest significant yield $(164.00 \mathrm{~kg})$ was recorded by the third tree in 2015, and $(162.00 \mathrm{~kg})$ by the fifth tree in 2016 . Meanwhile, the lowest yield $(106.66 \mathrm{~kg})$ was obtained by the fourth tree, in the first season, and $(117.33 \mathrm{~kg})$ was obtained by tree No. 8 in the second season.

These findings are in line with those of ElHamadi et al. (1977) and Al-Hamoudi et al. (2006). They recorded variable degree of compatibility in some date varieties and variable fruit set percentage.

\subsubsection{Fruit physical properties.}

Fruit weight: The results illustrated in Table (3) and Fig (1) showed that the third and the ninth female trees had the highest value of fruit weight $(25.96 \mathrm{~g})$, in the first season, while the fifth tree had the lowest value $(10.23 \mathrm{~g})$. In the second season, also the highest value was for the third tree $(27.16 \mathrm{~g})$ and the lowest was for the fifth tree $(10.76 \mathrm{~g})$.

Fruit size: The data revealed that the two trees ( number 3 and 9), gave the highest value of fruit size $\left(24.40\right.$ and $\left.20.43 \mathrm{~cm}^{3}\right)$ respectively, in the first season, the lowest value was for the fifth tree $\left(9.26 \mathrm{~cm}^{3}\right)$. In the second season, the highest value was for the third tree $\left(26.02 \mathrm{~cm}^{3}\right)$, while the fifth tree gave the lowest $\left(10.46 \mathrm{~cm}^{3}\right)$.

Fruit diameter: Regarding the fruit diameter. The data showed that the highest and significant value was for the third tree $(2.54$ and $2.67 \mathrm{~cm})$, in 2015 and 2016, respectively. In the first season, the lowest values were for the egith and ninth trees $(1.09 \mathrm{~cm}$ and $1.10 \mathrm{~cm})$, respectively. Only the ninth tree gave the lowest value (1.18 $\mathrm{cm}$ ) in the second season.

Fruit length: As for the length, the third tree only gave the highest value $(3.23 \mathrm{~cm})$, in 2015 . In the second season, the trees number $(2,3,6$, 9, 10 and Barhi) gave the highest values ranging from 2.54 to $3.15 \mathrm{~cm}$. The lowest values were for the fivth and seventh trees (1.28 and 1.29 $\mathrm{cm}$ ), in the first season. In 2016, the trees number 4 and 5 had values 1.76 and $1.74 \mathrm{~cm}$, respectively.

Metwaly et al. (2009) evaluated the seeded date palm trees grown under Fayoum Governorate. El Mergheny and Zaen El-Dean (2013), studied the fruit physical properties of some cultivars of date palm and stated that Sokkary and Barhee (soft date palm cultivars) were the best soft date palm cultivars.

Flesh weight: The obtained results indicated that the flesh weight of fruits differed significantly according to the type of females. The third tree gave the highest values (24.60 and $24.43 \mathrm{~g}$ ). The fifth tree gave the lowest $(9.08$ and $9.31 \mathrm{~g}$ ), 
Table (2): Dates of first and last spathe, periods of flowerings No of spath/tree, fruit set percentage and yield/tree of ten different female type Barhi date cv. During 2015 and 2016

\begin{tabular}{|c|c|c|c|c|c|c|c|c|c|c|c|c|}
\hline \multirow{3}{*}{$\begin{array}{c}\text { Female } \\
\text { No. } \\
1\end{array}$} & \multicolumn{4}{|c|}{ First spathe date } & \multicolumn{4}{|c|}{ Last spathe date } & \multicolumn{4}{|c|}{ Period of flow erring/ day } \\
\hline & \multicolumn{2}{|c|}{2015} & \multicolumn{2}{|c|}{2016} & \multicolumn{2}{|c|}{2015} & \multicolumn{2}{|c|}{2016} & \multirow{2}{*}{\multicolumn{2}{|c|}{$\begin{array}{l}\mathbf{2 0 1 5} \\
19 \\
\end{array}$}} & \multirow{2}{*}{\multicolumn{2}{|c|}{$\begin{array}{l}\mathbf{2 0 1 6} \\
25\end{array}$}} \\
\hline & 5 & Mar & 28 & Feb & 24 & Mar & 25 & Mar & & & & \\
\hline 2 & 7 & Mar & 2 & Mar & 28 & Mar & 1 & Apr & \multicolumn{2}{|l|}{21} & \multicolumn{2}{|l|}{30} \\
\hline 3 & 7 & Mar & 2 & Mar & 1 & Apr. & 1 & Apr & \multicolumn{2}{|l|}{25} & \multicolumn{2}{|l|}{30} \\
\hline 4 & 11 & Mar & 1 & Mar & 31 & Mar & 31 & Mar & \multicolumn{2}{|l|}{20} & \multicolumn{2}{|l|}{30} \\
\hline 5 & 15 & Mar & 11 & Mar & 28 & Mar & 25 & Mar & \multicolumn{2}{|l|}{13} & \multicolumn{2}{|l|}{114} \\
\hline 6 & 15 & Mar & 14 & Mar & 1 & Apr. & 2 & Apr & \multicolumn{2}{|l|}{17} & \multicolumn{2}{|l|}{19} \\
\hline 7 & 15 & Mar & 11 & Mar & 2 & Apr. & 2 & Apr & \multicolumn{2}{|l|}{18} & \multicolumn{2}{|l|}{22} \\
\hline 8 & 12 & Mar & 2 & Mar & 1 & Apr. & 1 & Apr & \multicolumn{2}{|l|}{19} & \multicolumn{2}{|l|}{30} \\
\hline 9 & 7 & Mar & 11 & Mar & 1 & Apr. & 11 & Apr & \multicolumn{2}{|l|}{25} & \multicolumn{2}{|l|}{31} \\
\hline 10 & 5 & Mar & 2 & Mar & 1 & Apr. & 1 & Apr & \multicolumn{2}{|l|}{27} & \multicolumn{2}{|l|}{30} \\
\hline Barhi & 11 & Mar & 6 & Mar & 1 & Apr. & 2 & Apr & \multicolumn{2}{|l|}{21} & \multicolumn{2}{|l|}{27} \\
\hline Female & & of $\mathrm{sp}$ & he / t & & & Frit & $\%$ & & & Id / & ee (kg) & \\
\hline No. & 2015 & & 2016 & & 20 & & 20 & & 201 & & 201 & \\
\hline 1 & 16 & & 18 & & 60.43 & $\mathrm{bc}$ & 55.20 & $a b$ & 119.00 & hi & 127.00 & ef \\
\hline 2 & 18 & & 20 & & 58.43 & $\mathrm{c}$ & 50.44 & $\mathrm{c}$ & 128.30 & $\mathrm{~d}$ & 152.00 & $\mathrm{c}$ \\
\hline 3 & 22 & & 22 & & 52.38 & $\mathrm{~d}$ & 54.94 & $a b$ & 164.00 & $\mathrm{a}$ & 158.00 & $\mathrm{~b}$ \\
\hline 4 & 14 & & 18 & & 58.76 & $\mathrm{c}$ & 52.30 & $\mathrm{bc}$ & 106.66 & $\mathrm{j}$ & 122.00 & $\mathrm{~g}$ \\
\hline 5 & 18 & & 22 & & 70.16 & $\mathrm{a}$ & 55.19 & $\mathrm{ab}$ & 134.00 & $\mathrm{c}$ & 162.00 & $\mathrm{a}$ \\
\hline 6 & 16 & & 18 & & 58.46 & c & 52.12 & $\mathrm{bc}$ & 122.00 & fg & 130.00 & $\mathrm{e}$ \\
\hline 7 & 15 & & 20 & & 60.72 & $\mathrm{bc}$ & 56.39 & $\mathrm{a}$ & 117.00 & $\mathrm{i}$ & 146.00 & $\mathrm{~d}$ \\
\hline 8 & 16 & & 14 & & 60.49 & $\mathrm{bc}$ & 54.99 & $a b$ & 120.00 & $\mathrm{gh}$ & 117.33 & $\mathrm{~h}$ \\
\hline 9 & 17 & & 16 & & 70.60 & $\mathrm{a}$ & 58.13 & $\mathrm{a}$ & 128.30 & $\mathrm{e}$ & 124.00 & $\mathrm{fg}$ \\
\hline 10 & 20 & & 18 & & 61.86 & $\mathrm{~b}$ & 51.37 & $\mathrm{c}$ & 154.00 & $\mathrm{~b}$ & 148.67 & $\mathrm{~cd}$ \\
\hline Barhi & 16 & & 18 & & 58.03 & $\mathrm{c}$ & 50.78 & c & 124.00 & $\mathrm{f}$ & 126.00 & $\mathrm{f}$ \\
\hline
\end{tabular}

Means in the same column followed by the same letter(s) are not significantly $(\mathrm{p} \geq 0.05)$ different

Table (3): Fruit weight, fruit size, fruit diameter, fruit length, flesh weight, seed weight and flesh percentage of ten Different female eypes of Barhi clate CV. During 2015 and 2016

\begin{tabular}{|c|c|c|c|c|c|c|c|c|c|c|c|c|}
\hline Female No. & \multicolumn{4}{|c|}{ Fruit weight (g) } & \multicolumn{4}{|c|}{ Fruit size (m3) } & \multicolumn{4}{|c|}{ Fruit diameter $(\mathrm{cm})$} \\
\hline & \multicolumn{2}{|c|}{2015} & \multicolumn{2}{|c|}{2016} & \multicolumn{2}{|c|}{2015} & \multicolumn{2}{|c|}{2016} & \multicolumn{2}{|c|}{2015} & \multicolumn{2}{|c|}{2016} \\
\hline 1 & 13.50 & c & 14.10 & $\mathrm{~d}$ & 13.03 & $\mathrm{c}$ & 14.00 & $\mathrm{c}$ & 1.24 & $\mathrm{~cd}$ & 1.55 & $\mathrm{c}$ \\
\hline 2 & 15.76 & $\mathrm{~b}$ & 16.56 & $\mathrm{bc}$ & 13.25 & $\mathrm{c}$ & 16.19 & $\mathrm{~b}$ & 1.33 & $\mathrm{~cd}$ & 1.52 & $\mathrm{~cd}$ \\
\hline 3 & 25.96 & $\mathrm{a}$ & 27.16 & $\mathrm{a}$ & 24.40 & $\mathrm{a}$ & 26.02 & $\mathrm{a}$ & 2.54 & $\mathrm{a}$ & 2.67 & $\mathrm{a}$ \\
\hline 4 & 13.30 & $\mathrm{c}$ & 14.06 & $\mathrm{~d}$ & 12.63 & $\mathrm{~cd}$ & 13.30 & $\mathrm{~cd}$ & 1.32 & $\mathrm{~cd}$ & 1.38 & $\mathrm{de}$ \\
\hline 5 & 10.23 & $\mathrm{~d}$ & 10.76 & $\mathrm{e}$ & 9.26 & $\mathrm{e}$ & 10.46 & $\mathrm{e}$ & 1.93 & $\mathrm{~b}$ & 2.11 & $\mathrm{~b}$ \\
\hline 6 & 16.33 & $\mathrm{~b}$ & 16.87 & $\mathrm{bc}$ & 15.96 & $\mathrm{~b}$ & 15.83 & $\mathrm{~b}$ & 1.32 & $\mathrm{~cd}$ & 1.36 & def \\
\hline 7 & 13.50 & $\mathrm{c}$ & 17.24 & $\mathrm{~b}$ & 13.30 & $\mathrm{c}$ & 15.95 & $\mathrm{~b}$ & 1.66 & $\mathrm{bc}$ & 2.04 & $\mathrm{~b}$ \\
\hline 8 & 13.76 & $\mathrm{~b}$ & 14.07 & $\mathrm{~d}$ & 15.53 & $\mathrm{~b}$ & 13.39 & $\mathrm{~cd}$ & 1.09 & $\mathrm{~d}$ & 1.21 & $f g$ \\
\hline 9 & 25.96 & $\mathrm{a}$ & 13.60 & $\mathrm{~d}$ & 20.43 & $\mathrm{a}$ & 12.80 & $\mathrm{~d}$ & 1.10 & $\mathrm{~d}$ & 1.18 & $\mathrm{~g}$ \\
\hline 10 & 13.30 & $\mathrm{c}$ & 16.91 & $\mathrm{~b}$ & 11.73 & $\mathrm{~d}$ & 15.84 & $\mathrm{~b}$ & 1.44 & $\mathrm{~cd}$ & 1.33 & efg \\
\hline Barhi & 11.80 & $\mathrm{~cd}$ & 16.18 & $\mathrm{c}$ & 11.56 & $\mathrm{~d}$ & 15.63 & $\mathrm{~b}$ & 2.03 & $\mathrm{~b}$ & 2.14 & $\mathrm{~b}$ \\
\hline Female No. & \multicolumn{4}{|c|}{ Flesh weight (g) } & \multicolumn{4}{|c|}{ Seed weight (g) } & \multicolumn{4}{|c|}{ Flesh percentage \% } \\
\hline & \multicolumn{2}{|c|}{2015} & \multicolumn{2}{|c|}{2016} & \multicolumn{2}{|c|}{2015} & \multicolumn{2}{|c|}{2016} & \multicolumn{2}{|c|}{2015} & \multicolumn{2}{|c|}{2016} \\
\hline 1 & 12.04 & $\mathrm{~cd}$ & 12.09 & $\mathrm{de}$ & 1.31 & bcd & 1.31 & $\mathrm{c}$ & 89.15 & def & 88.73 & $\mathrm{fg}$ \\
\hline 2 & 14.12 & $\mathrm{~b}$ & 14.13 & $\mathrm{c}$ & 1.49 & $\mathrm{~b}$ & 1.39 & $\mathrm{bc}$ & 89.56 & $\mathrm{de}$ & 89.42 & ef \\
\hline 3 & 24.60 & $a$ & 24.43 & $a$ & 1.19 & $\mathrm{~cd}$ & 1.22 & $\mathrm{~d}$ & 94.71 & $a$ & 94.74 & $\mathrm{a}$ \\
\hline 4 & 11.90 & $\mathrm{~cd}$ & 12.72 & $\mathrm{~d}$ & 1.24 & $\mathrm{~cd}$ & 1.36 & $\mathrm{bc}$ & 89.45 & $\mathrm{de}$ & 89.50 & def \\
\hline 5 & 9.08 & $\mathrm{e}$ & 9.31 & $\mathrm{f}$ & 1.00 & $\mathrm{e}$ & 1.11 & $\mathrm{e}$ & 88.72 & ef & 89.81 & $\mathrm{de}$ \\
\hline 6 & 14.83 & $\mathrm{~b}$ & 15.65 & $\mathrm{~b}$ & 1.35 & $\mathrm{bc}$ & 1.46 & $\mathrm{~b}$ & 90.81 & $\mathrm{bcd}$ & 90.81 & $\mathrm{c}$ \\
\hline 7 & 14.98 & $\mathrm{~b}$ & 15.30 & $\mathrm{~b}$ & 1.13 & de & 1.23 & $\mathrm{~d}$ & 91.93 & $\mathrm{~b}$ & 92.12 & $\mathrm{~b}$ \\
\hline 8 & 12.43 & $\mathrm{c}$ & 12.64 & $\mathrm{~d}$ & 1.12 & $\mathrm{~cd}$ & 1.29 & $\mathrm{~cd}$ & 90.12 & cde & 90.46 & $\mathrm{~cd}$ \\
\hline 9 & 11.25 & d & 11.49 & $\mathrm{e}$ & 1.34 & $\mathrm{bc}$ & 1.32 & $\mathrm{c}$ & 87.46 & $\mathrm{f}$ & 88.41 & $\mathrm{~g}$ \\
\hline 10 & 14.34 & $\mathrm{~b}$ & 14.15 & $\mathrm{c}$ & 1.77 & $\mathrm{a}$ & 1.94 & $\mathrm{a}$ & 89.14 & def & 87.79 & $\mathrm{~g}$ \\
\hline Barhi & 14.38 & $\mathrm{~b}$ & 14.28 & $\mathrm{c}$ & 1.23 & $\mathrm{~cd}$ & 1.38 & $\mathrm{bc}$ & 91.38 & $\mathrm{bc}$ & 91.11 & $\mathrm{C}$ \\
\hline
\end{tabular}

Means in the same column followed by the same letter(s) are not significantly ( $\mathrm{p} \geq 0.05)$ different. 

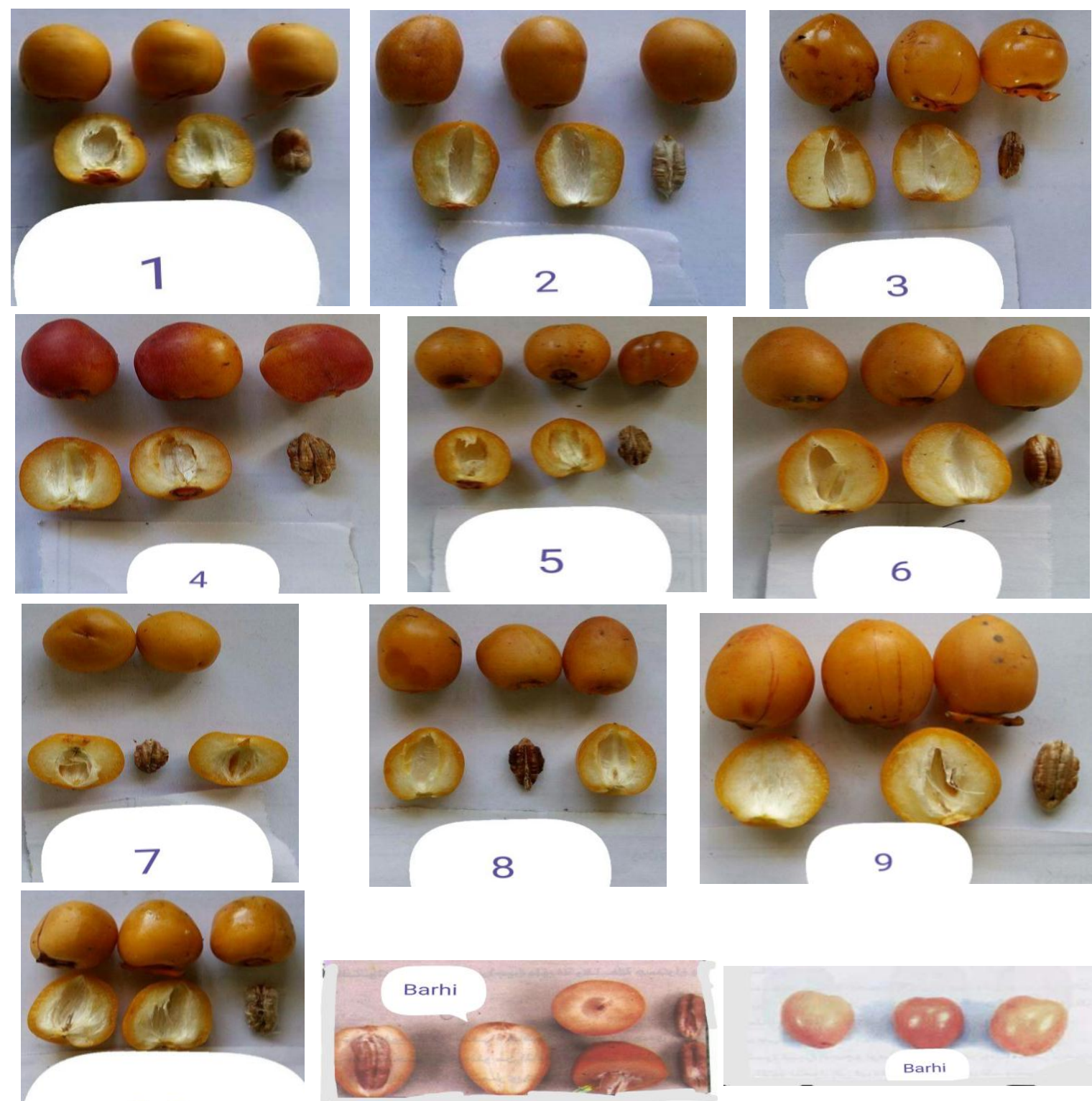

10

Fig. (1): Fruit shape and fruit quality of ten seeded female date palms under study, and fruit of Barhi cv.

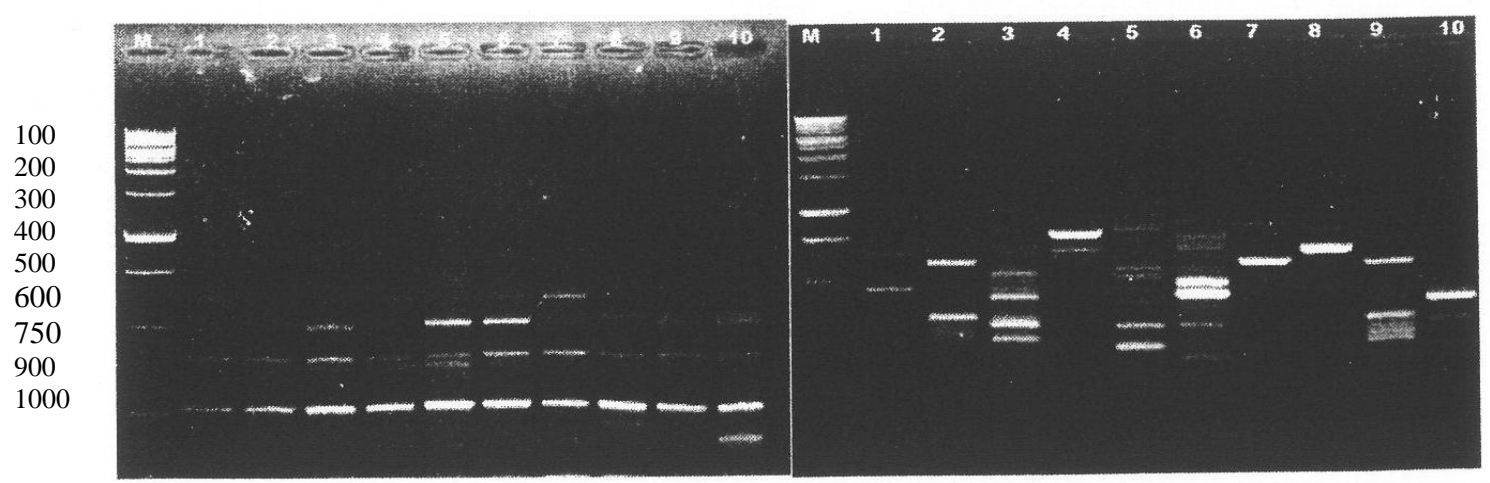

Fig. (2): Polymorphism detected by I SSR (IS2 and IS6) marker with ten selected date palm females M: Ladder molecular weight marker. 
respectively in the two seasons under study.

Seed weight: On the other hand, the lowest weight of seed was for the fifth tree (1.00 and $1.11 \mathrm{~g}$ ), while the highest weight was for tree number 10 (1.77 and $1.94 \mathrm{~g}$ ) in 2015 and 2016, respectively.

Flesh percentage: Regardling the flesh percentage, data revealed that there were significant differences among the different types of female. The third tree had the highest percentage (94.71\% and $94.74 \%$ ) in the two seasons under study, respectively. In the 2015 , only one type (ninth tree) had the lowest percentage $87.46 \%$ while in 2016 , the two trees (ninth and tenth) had the lowest percentages (88.41 and $87.79 \%)$, respectively.

These results are in harmony with those found by Metwaly et al. (2009) who evaluated some seeded date palm trees grown in Fayoum Governorate, and identified six semi-dry seeded date palms and four soft date palms.

\subsubsection{Fruit chemical properties}

Total soluble solid contents: The results presented in Table (4) showed TSS\% of ten female types and Barhi cv. In the two seasons 2015 and 2016. The sixth type (tree 6) gave the highest values in the two seasons (44.65 and $44.49 \%$ ), respectively, while the first type gave the lowest (30.54 and 30.91\%), respectively.

Total sugars percentage: the data presented in Table (4) indicated significant differences in the total sugars content among the studied ten female types and Barhi cultivar in the two seasons. The two types (seventh and Barhi cv.) gave the highest values (71.00 and 71.34\%), respectively, in the first season. In the second season, the types (seventh, tenth and Barhi cv. gave percentages ranged between 70.00 to $71.10 \%$. Concerning the lowest value, it was for the forth type in the two seasons under study (21.18 and $22.16 \%)$, respectively.

Reducing sugar percentage: The results in Table (4) indicated significant differences of reducing sugars among the studied types of female trees. Fruits of trees number ( 8 and Barhi cv. gave the highest values 33.47 and $33.21 \%$ ), in the first season, and 34.11 and $33.29 \%$ for trees number (7) and Barhi cv. in the second season, respectively. On the other hand, the lowest reducing sugar percentage was recorded by two types (tree 4 and tree 9) 14.78 and $14.63 \%$, respectively, in 2015. Whereas only the forth type (tree 4) gave the lowest significant value (14.87\%) in 2016 for reducing sugar percentage.
Non reducing sugar percentage: The convent data revealed that three types of female (trees 7, 10 and Barhi cv.) gave the highest percentage ranged between 38.12 to $39.04 \%$ in the first season. Meanwhile only the type number (10) gave the highest value $(41.57 \%)$, in the second season. Concerning the lowest value, the data indicated that the trees number 4 and 6 had the significant nonproducing sugar percentage $(6.40$ and $7.00 \%$ ), in 2015 and (7.48 and $7.79 \%)$ in 2016, respectively.

These results are in line with Metwaly et al. (2009), who noted four seeded palm trees of soft dates selected comparing with Zaghloul cultivar.

Tannins content: The data presented in Table (5) cleared that the average tannins content ranged between 0.472 (for the ninth female tree) and 0.255 (for the first female tree), in the first season 2015. In the second season this average ranged between 0.465 ( for the ninth female tree) and to 0.257 ( for first female tree).

Carotenes percentage: The results in Table (5) indicated significant differences among the studied ten types of seeded female date palm trees and Barhi cv. In the first season, the two types (trees number 1 and 8) gave the highest values of carotene pigment (1.120 and $1.220 \%$ ) respectively, whereas only tree number (8) gave the highest value $(1.202 \%)$ in the second season. On the other hand, the lowest percentage of pigment was for the second type only (0.266 and $0.290 \%$ ), in 2015 and 2016 seasons, respectively.

Chlorophyll a percentage: It is worth noting that the percentages of chlorophyll a for all the trees under study were in the same trend in the two seasons. The second type of female tree gave the highest percentage (0.501 and $0.487 \%)$, respectively. The seventh and ninth types of seeded female palms gave the lowest values $(0.091$ and $0.095 \%)$ in the first season and $(0.096$ and $0.097 \%)$ in the second season.

Chlorophyll b percentage: It is clear from the data in Table (5) that significant differences was found between ten types of seeded female of date palm date and Barhi cv. The second type (tree number 2) gave the highest values $(0.385$ and $0.377 \%$ ), in the two seasons under study, respectively. On the other hand, two types (trees no. 7 and 8) gave the lowest percentage of chlorophyll b (0.062 and $0.064 \%)$, in the first season. There were four types (trees number 7,8,10 and Barhi cv.) gave the lowest percentage ranged between 0.059 to $0.075 \%$, in the second season. 
Table (4): Total soluble sugar percentage, total sugar percentage, reducing sugar percentage and nonproducing sugar percentage of ten different female types of Barhi date palm cultivar during 2015 and 2016

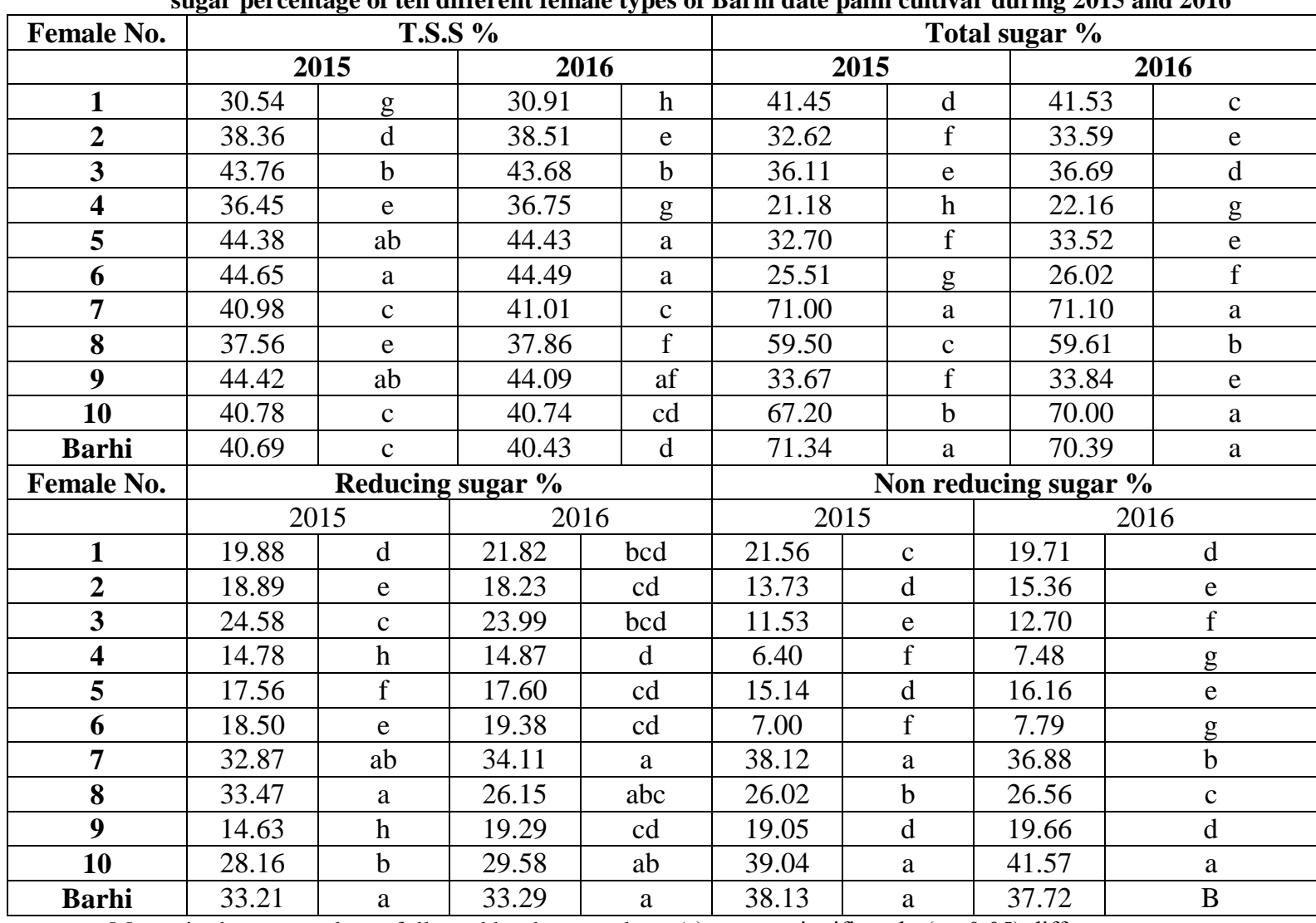

Means in the same column followed by the same letter(s) are not significantly $(\mathrm{p} \geq 0.05)$ different.

Table (5): Some fruit chemical properties of the ten female types of Barhi date palm cv. During 2015 and 2016 seasons.

\begin{tabular}{|c|c|c|c|c|c|c|c|c|}
\hline \multirow{3}{*}{$\begin{array}{c}\text { Female No. } \\
1\end{array}$} & \multicolumn{4}{|c|}{ Tannins \% } & \multicolumn{4}{|c|}{ Carotenes \% } \\
\hline & \multicolumn{2}{|c|}{2015} & \multicolumn{2}{|c|}{2016} & \multicolumn{2}{|c|}{2015} & \multicolumn{2}{|c|}{2016} \\
\hline & 0.255 & $\mathrm{f}$ & 0.257 & $\mathrm{f}$ & 1.120 & $\mathrm{a}$ & 1.029 & $\mathrm{~b}$ \\
\hline 2 & 0.405 & $\mathrm{bc}$ & 0.400 & $\mathrm{~b}$ & 0.266 & $\mathrm{~h}$ & 0.290 & $\mathrm{~h}$ \\
\hline 3 & 0.340 & $\mathrm{~d}$ & 0.337 & $\mathrm{~d}$ & 0.562 & $\mathrm{e}$ & 0.571 & $\mathrm{e}$ \\
\hline 4 & 0.342 & $\mathrm{~d}$ & 0.355 & $\mathrm{c}$ & 0.634 & $\mathrm{c}$ & 0.647 & $\mathrm{~cd}$ \\
\hline 5 & 0.285 & $\mathrm{e}$ & 0.281 & $\mathrm{e}$ & 0.672 & $\mathrm{~b}$ & 0.680 & $\mathrm{c}$ \\
\hline 6 & 0.424 & $\mathrm{~b}$ & 0.410 & $\mathrm{~b}$ & 0.353 & $\mathrm{~g}$ & 0.362 & $\mathrm{~g}$ \\
\hline 7 & 0.335 & $\mathrm{~d}$ & 0.333 & $\mathrm{~d}$ & 0.603 & $\mathrm{~d}$ & 0.639 & $\mathrm{~cd}$ \\
\hline 8 & 0.409 & $\mathrm{bc}$ & 0.407 & $\mathrm{~b}$ & 1.220 & $\mathrm{a}$ & 1.202 & $\mathrm{a}$ \\
\hline 9 & 0.472 & $\mathrm{a}$ & 0.465 & $\mathrm{a}$ & 0.604 & $\mathrm{~d}$ & 0.618 & $\mathrm{~d}$ \\
\hline 10 & 0.327 & $\mathrm{~d}$ & 0.333 & $\mathrm{~d}$ & 0.452 & $\mathrm{f}$ & 0.461 & $\mathrm{f}$ \\
\hline Barhi & 0.402 & $\mathrm{c}$ & 0.400 & $\mathrm{~b}$ & 0.657 & $\mathrm{bc}$ & & $\mathrm{cd}$ \\
\hline Female No. & \multicolumn{4}{|c|}{ Chlorophyll a \% } & \multicolumn{4}{|c|}{ Chlorophyll b \% } \\
\hline & \multicolumn{2}{|c|}{2015} & \multicolumn{2}{|c|}{2016} & \multicolumn{2}{|c|}{2015} & \multicolumn{2}{|c|}{2016} \\
\hline 1 & 0.115 & $\mathrm{~h}$ & 0.126 & $\mathrm{~g}$ & 0.133 & $\mathrm{c}$ & 0.134 & $\mathrm{bc}$ \\
\hline 2 & 0.501 & $\mathrm{a}$ & 0.487 & $\mathrm{a}$ & 0.385 & $\mathrm{a}$ & 0.377 & $\mathrm{a}$ \\
\hline 3 & 0.374 & $\mathrm{~b}$ & 0.386 & $\mathrm{~b}$ & 0.256 & $\mathrm{~b}$ & 0.261 & $\mathrm{abc}$ \\
\hline 4 & 0.196 & $\mathrm{e}$ & 0.197 & $\mathrm{~d}$ & 0.089 & $\mathrm{e}$ & 0.090 & $\mathrm{bc}$ \\
\hline 5 & 0.196 & $\mathrm{f}$ & 0.163 & $\mathrm{e}$ & 0.104 & $\mathrm{~d}$ & 0.104 & $\mathrm{bc}$ \\
\hline 6 & 0.224 & $\mathrm{~d}$ & 0.218 & $\mathrm{~d}$ & 0.129 & $\mathrm{c}$ & 0.127 & $\mathrm{bc}$ \\
\hline 7 & 0.091 & $\mathrm{i}$ & 0.096 & $\mathrm{~h}$ & 0.062 & $\mathrm{~h}$ & 0.059 & $\mathrm{c}$ \\
\hline 8 & 0.283 & c & 0.270 & $\mathrm{c}$ & 0.064 & $\mathrm{~h}$ & 0.063 & $\mathrm{c}$ \\
\hline 9 & 0.095 & $\mathrm{i}$ & 0.097 & $\mathrm{~h}$ & 0.089 & $\mathrm{f}$ & 0.323 & $a b$ \\
\hline 10 & 0.135 & $\mathrm{~g}$ & 0.138 & $\mathrm{fg}$ & 0.072 & $\mathrm{~g}$ & 0.075 & $\mathrm{c}$ \\
\hline Barhi & 0.158 & $\mathrm{f}$ & 0.160 & ef & 0.067 & gh & 0.063 & $\mathrm{C}$ \\
\hline
\end{tabular}

Means in the same column followed by the same letter(s) are not significantly $(\mathrm{p} \geq 0.05)$ different. 
It is noted that chlorophyll $(a+b)$ precede negatively and significantly correlated with carotene percentage. Also carotene was negatively and significant correlated with nonproducing sugars as shown in Table (5).

Bacha et al. (1987) studied the physical and chemical characteristics of the fruits of date palms in some cultivars during three stages (Kimri, Khalal and Tamar). They stated that pigment contents (chlorophyll $\mathrm{a}+\mathrm{b}$ and carotene) were high in the Kimri stage greatly reduced in the other two stages. Shaheen et al. (1989a) stated that pigment contents (Chlorophyll $\mathrm{a}+\mathrm{b}$ and carotene) were high in the Kimri stage.

\subsection{Genetic studies}

\subsubsection{Polymorphism and genetic similarity estimated by ISSR markers}

Table (6) summarizes the results obtained from using ten primers of ISSR marker. All of the ten tested primers were reproducible and scorable (Fig. 2) Two primers represent $100 \%$ polymorphic amplicons (4 and 9). On the other hand, primers No 7 and 2 recorded the highest percentage of polymorphism (94.4 and 92.9, respectively). Primer No.2 produced the highest number of amplicons (28), two of these ampl icons were monomorphic, while twenty-six were polymorphic. Average number of amplicons produced by the ten primers was 20.7, 2.5 of these amplicons were monomorphic and 18.2 were polymorphic. In this regard, Ameer et al., (2016) stated that seven ISSR primers for twenty five date palm cultivars produced a total of 622 bands with an average of 38.8 bands per primer.
The number of distinct bands for each primer ranged from 1 to 7. Meanwhile Abd-Alla (2010) mentioned that DNA bands generated with the primer HB-15 ranged from 7 to 9 .

\subsubsection{Genetic Similarity}

Genetic similarity was estimated according to Dice coefficient (Sneath and Sokal, 1973). The genetic similarity ranged from $11 \%$ to $64.1 \%$ (Table 7). The highest genetic similarity (64.1\%) was between strain No 9 and strain No 1 . However, the lowest genetic similarity was recorded between strain No.7 and strain No.9. It is obvious that genetic similarity between the tested strains were very low, this may attributed to its origin as seeds. In this respect, Hamza et al. (2012) observed the highest genetic distance 0.48 and 0.05 among date palm cultivars based on ISSR data. Interestingly the highest and lowest genetic similarities have divided the date palm cultivars geographically, The cultivars having the highest similarity belong to Sinolh and with low similarity belong to Baluchistan provinces, respectively.

\subsubsection{Cluster Analysis}

Dendrogram obtained from UPGMA cluster analysis of genetic distances (Fig. 3) revealed that all of the tested genotypes were separated into two clusters. The first cluster was divided into two groups. One of these groups contained strains No 5, No8 and No3. However, the second one includes strain No 10 only. The second cluster was also divided into two groups, the first one grouped strains No 7, No 4, No 6 and No2. While the second group contained strains No.9 and No.1. 1. Ameer et al., (2016)

Table (6): Primer sequence, Monomoraphic bands, Polymorphic bands, total number of bands, number of and percentage of polymorphism of ten date palm females lines.

\begin{tabular}{|c|c|c|c|c|}
\hline $\begin{array}{c}\text { Number of } \\
\text { Primer }\end{array}$ & $\begin{array}{c}\text { Monomorphic } \\
\text { bands }\end{array}$ & $\begin{array}{c}\text { Number of } \\
\text { polymorphic } \\
\text { bands }\end{array}$ & $\begin{array}{c}\text { Total number } \\
\text { of bands }\end{array}$ & $\begin{array}{c}\text { Percentage of } \\
\text { polymorphic } \\
\text { bands }\end{array}$ \\
\hline 1 & 4 & 21 & 25 & 84.0 \\
2 & 2 & 26 & 28 & 92.9 \\
3 & 2 & 19 & 21 & 90.5 \\
4 & 0 & 18 & 18 & 100 \\
5 & 3 & 15 & 18 & 83.3 \\
6 & 6 & 20 & 26 & 76.9 \\
7 & 1 & 17 & 18 & 94.4 \\
8 & 3 & 13 & 16 & 81.3 \\
9 & 0 & 16 & 16 & 100 \\
10 & 4 & 17 & 21 & 80.9 \\
\hline Total & 25 & 182 & 207 & 88.42 \\
Mean & 2.5 & 18.2 & 20.7 & \\
\hline
\end{tabular}


Table (7): Genetic similarity matrices computed according to Dice Coefficient from ISSR markers.

\begin{tabular}{|l|c|c|c|c|c|c|c|c|c|c|}
\hline & $\mathbf{D}_{\mathbf{1}}$ & $\mathbf{D}_{\mathbf{2}}$ & $\mathbf{D}_{\mathbf{3}}$ & $\mathbf{D}_{\mathbf{4}}$ & $\mathbf{D}_{\mathbf{5}}$ & $\mathbf{D}_{\mathbf{6}}$ & $\mathbf{D}_{\mathbf{7}}$ & $\mathbf{D}_{\mathbf{8}}$ & $\mathbf{D}_{\mathbf{9}}$ & $\mathbf{D}_{\mathbf{1 0}}$ \\
\hline $\mathbf{D}_{\mathbf{1}}$ & & & & & & & & & & \\
\hline $\mathbf{D}_{\mathbf{2}}$ & 20.3 & & & & & & & & & \\
\hline $\mathbf{D}_{\mathbf{3}}$ & 18.9 & 23.4 & & & & & & & & \\
\hline $\mathbf{D}_{\mathbf{4}}$ & 40.1 & 11.4 & 12.4 & & & & & & & \\
\hline $\mathbf{D}_{\mathbf{5}}$ & 24.1 & 24.7 & 14.1 & 17.2 & & & & & & \\
\hline $\mathbf{D}_{\mathbf{6}}$ & 18.5 & 51.2 & 21.3 & 16.4 & 21.4 & & & & & \\
\hline $\mathbf{D}_{\mathbf{7}}$ & 15.9 & 13.4 & 35.1 & 24.3 & 17.1 & 33.1 & & & & \\
\hline $\mathbf{D}_{\mathbf{8}}$ & 11.7 & 22.2 & 13.5 & 27.1 & 24.2 & 14.2 & 24.1 & & & \\
\hline $\mathbf{D}_{\mathbf{9}}$ & 64.1 & 30.7 & 14.5 & 14.2 & 21.3 & 18.4 & 11.0 & 21.3 & & \\
\hline $\mathbf{D}_{\mathbf{1 0}}$ & 28.1 & 18.2 & 34.1 & 41.2 & 10.3 & 20.3 & 34.1 & 24.0 & 21.7 & \\
\hline
\end{tabular}

computed the genetic similarity index through Dice coefficient. Cluster 1 comprised 4 date palm cultivars. The cultivars Kupro and Gulistan showed close relationship in comparison with otaqin and Mazawati cultivars. Cluster 2 was further divided into 5 subculsters, the highest similarity was observed between Asul Kurh and Gajar. The cultivars Sher Shahi Dokka, Seedless. Shakkar and Shakkri also showed close relationship in two-sub-clusters but the cultivars Khar, Begum Tangi and Babac were also at distant from all the cultivars and did not lie in any subcluster. ISSR has proved successful for assessing genetic diversity within various plant groups for gene mapping and for germplasm identification (Santos et al., 2012).

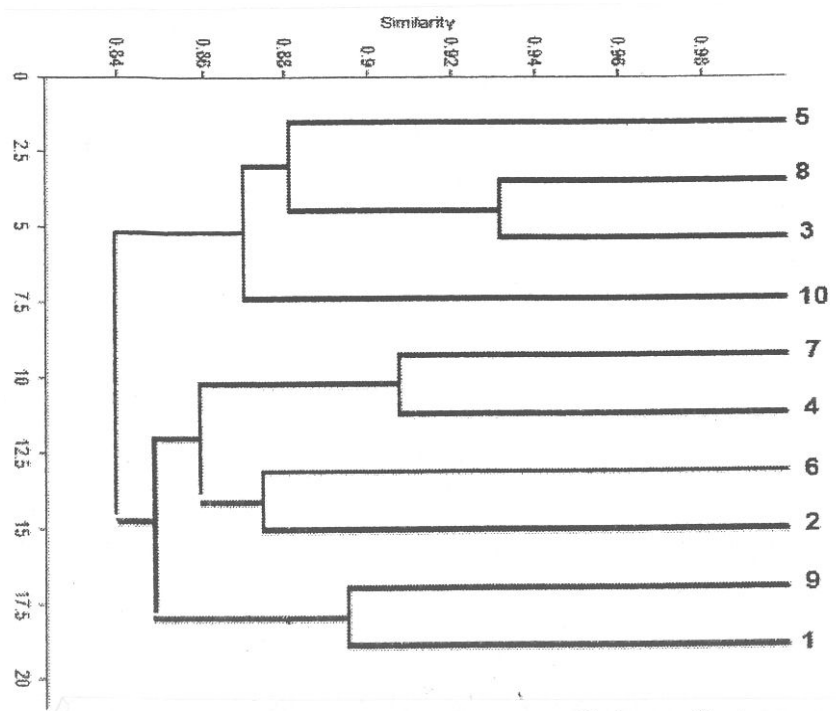

Fig. (3): Dendrogram using average linkage (between groups).

\section{Conclusion}

This investigation introduced ten female seeded date palms, namely palm Nos. 1 to 10 compared with Barhi cv. It was found that trees number 3.5 and 9 were superior in their yield, trees number 3 and 9 were superior in weight and shape of fruit and flesh percentage. Trees number $1,5,8$ and 9 were superior in fruit chemical characteristics. Therefore, the tested seeded female palms are considered promising palm trees for producing Barhi (soft dates) as an initial date palm cultivars under Alexandria Governorate. The results of molecular analysis of the genomic DNA of the ten seeded female date palms showed that the total number of amplicons amplified by the ten primers was 207 with an average $20.7 /$ primer. The polymorphism ranged from $100 \%$ to $76.9 \%$. The genetic similarity ranged from $11 \%$ to $64.1 \%$. The genetic similarity between the tested lines was very low, may be due to its origin as seeds. This polymorphism renders these markers useful for further genetic studies in female date palm trees.

\section{REFERENCES}

Abd-Alla M.M. (2010). Genetic stability of Phoenix dactylifera var. New York Sci. J. 3(12): $70-75$.

Al-Hamoudi A. H., El-Hammady A. M., Desouky L. M. and Abed El Hamid A. (2006). Evaluation of some male types as pollinators for Barhi date palm cv. Grown in Egypt. Arab. Univ. J. Agric. Sci., Ain Shams Univ., Cairo, 14 (1): 365-377.

Al-Juhaimi F., Ghafoor K. and Ozcan M. M. (2012). Physical and chemical properties, antioxidant activity, total phenol and 
mineral profile of seeds of seven different date fruit (Phoenix dactyllifera L.) varieties. Int., J. food Sci., and Nutr., 63(1):84-89.

Al-Rawahi A. S., Kasapis S. and Al-Bulushi I. M. (2005). Development of a date confectionary: Part 1. Relating formulation to instrumental texture Int' $1 . j$. Food Prop. 8:457-468.

Al-Redhaiman K. N. (2005). Chemical Changes during storage of 'Barhi' dates under controlled atmosphere conditions. Hort Sci. 40(5): 1413-1415.

Ameer H. M., Saifullahk., Sar war H.G., Naheed K. and Rafats S. (2016). DNA Fingerprinting of some Pakaistani date plam (Phone dactylifera $\mathrm{L}$.) cultivars using ISSR markers. Pak. J. Bot., 48(5): 20052010.

A.O.A.C. (1995). Official Methods of Analysis $15^{\text {th }}$ Edn., Association of Official Analytical Chemists, Washington DC., USA., pp: 440-510.

Aradhya M. (2006). Low genetic diversity and lack of genetic differentiation in Punica as evidenced by amplified fragment length polymorphysms, P.64 In:ISHS. 1 Int. Symp. Pomegranate and Minok Mediterranean Fruits, Abstracts contributed papers, 16-19 Oct., Adana Turkey.

Bacha M.A., Nasr T.A. and Shaheen M.A. (1987). Changes in physical and chemical characteristics of the fruits of four date palm cultivars. Proc. Saudi. Biol. Soc., 10:285-295.

Duncan D.B. (1955). Multiple range and multiple $\mathrm{F}$ tests. Biometrics, 11:1-42.

El-Hamadi M.M., Khalifah A.S. and El-Hamadi A.M. (1977). The effect of date pollen on some physical and chemical characters on Hayani variety. Res. Bull. Fac. Agric. Ain Shams Univ., Cairo, Egypt, Bulletin No. 733.

El-Merghany S. and Zaen El-Dean E. M. A. (2013). Evaluation of some date plam cultivars grown under Toshky conditions. J. Plant product, Mansoura Univ., 4 (8) : 1207-1218.

Hamza H., BenAbderrahim M. A., El bekkay M., Ferdaous G., Triki T. and Ferchi Chi A. (2012). Investigation of genetic variation in Tunisian date palm (Phoenix dactylifera L.) cultivars using ISSR marker systems and their relation with fruit characteristics. Turk. J. Biol., 36 : 440-458.

Ismail B., Haffar I., Baalbaki R. and Henry J. (2008). Physico chemical characteristics and sensory quality of two date cultivars under commercial and industrial storage conditions. Sci. Direct, 41: 896-904.

Jbir R., Hasnaoui N., Trifi M., Marrakchi M. and Mars M. (2006). Molecular polymorphism in Tunisian pomegranate (Punica granatum L.) cultivars as related by AFL. PP.71 In : ISHS1" Int Symp. Pomegranate and Minor Mediterranean Fruits. Abstracts contributzed papers 16-19 Oct. Adana Turkey.

Metwaly H.A.A., Abou-Rekab Z.A.M., Abd ElBaky A. A. and El-Bana A. A. (2009). Evaluation of some seeded date palm trees grown in Fayoum Governorate. BChemical characteristics. $4^{\text {th }}$ Conference on Recent Technologies in Agriculture.

Mohamed S.G., Abd-Allah B. M. and Mostafa F.M.A. (2004). Comparative study on some Iraqi date palm grown under middle and upper Egypt. Climatic conditions. Egypt J. Appl. Sci., 19 : 339-354.

Nei M. and Li.W.(1979). Mathematical model for studying genetic variation in terms of restriction endonucleases. Proc. Nat. Acad. Sci. USA (10): 5269-5273.

Porebski S., Bailey L.G. and Baum B.R. (1997). Modification of a CTAB DNA extraction protocol for plants containing high polysacch arids and polyphenol components. Plant Mol. Bio Rep. 15 :815.

Resenabatt M. and Pluso J.V. (1941). Determination of tannins by spectrophotometer. J. Asso. Offic. Agr. Chemists, $24: 170$.

Rizk R. M., El-Shrabasy and Soliman KH. A. (2007). Characterization and evaluation of six males date paln (Phoenix dectyliferael.) genotypes in Egypt. The fourth Symposium on date palm in King Faisl Univ. Al-Hassa, Saudi Arabia, 5-8 May, pp.238.

Rokba A.M., Seif S. A. and Abou El-Azayem A. L. (1990). Biological studies on some date palm seedlings grown in Fayoum Governorate. J. Agric. Sci. Mansoura Univ., 15(2) : 232-238.

Santos L.F., Oliveria EJ., Silva A.S., Cervalho F.M., Costa J.L. and Radua J.G. (2012). ISSR markers as a tool for the assessment 
of genetic diversity in Passiflora, Biochem. Genet.45:540-554.

Shaheen M.A., Bacha M.A. and Nasr T.A. (1989a). Effect of male type on fruit chemical properties in some date palm cultivars. Ann. Agric. Sci. Fac. Agric., 34:265-281.

Sneath P.H.A. and Sokal R.R. (1973). Numerical taxonomy. Freeman (pub.), San Francisco, California,USA.

Snedecor G. W. and Cochran W.G. (1980). Statistical Methods. $5^{\text {th }}$ Edn., Iowa State Universty Press., Ames, Iowa, USA., pp593.

Yilmaz M., Aka-Kacer Y., Yalcin-Mendi Y. and Ozguven A. L. (2006). Molecular characterization of some pomegranate (Punica granatum L.) genotypes by RAPD markers PP72 in ISHS 1 "Int. Symp Pomegranate and Mediteranean Fruits, Abstracts contributed papers 16-19 Oct., Ad ana Turkey.

Wensttein D. U.(1957). Chlorophyll letale and Der Supuni Kros Kapisene for Winneck Sec. Der. Plastiden. Experimental Cell. Research, 12:427.

Zamani Z., Sarkhosh A., Fatahi R. and Ebadi A. (2007). Genetic relationships among pomegranate genotypes studied by fruit characteristics and RAPD markers. J, Mort. Sci Biot., 82,11018.

$$
\begin{aligned}
& \text { تقييم وإنتخاب سلالات بذريه جديده من نخيل البارحى تحت ظروف إند محافظة الإسكندرية } \\
& \text { 3- توصيف عشر تراكيب وراثيه جديده من اناث نخيل الجيل البارحى البذريه } \\
& \text { حسن علي العشري } \\
& \text { قسم بحوث تربية اشجار الفاكهة و الزينة الخشبية ـ معهد بحوث البساتين ـ مركز البحوث الزر اعية ـ الاسكندرية ـ مصر } \\
& \text { ملخص } \\
& \text { بدأت هذه الدراسه سنة } 2015 \text { - } 2016 \text { فيى محطة البحوث الزربه اعبه بالصبحية ـ محافظة الإسكندرية من خلال }
\end{aligned}
$$

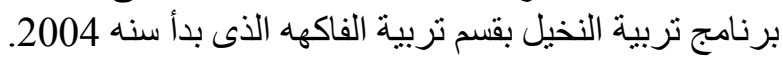

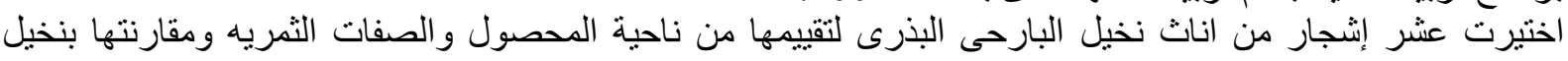

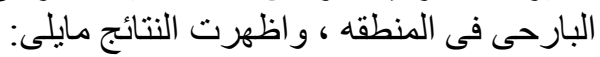

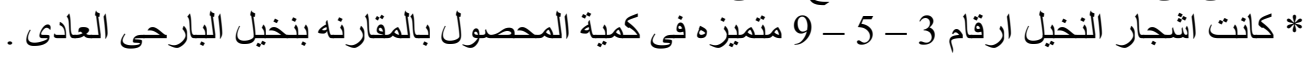

$$
\begin{aligned}
& \text { * كانت اشجار النخيل ارقام 3-9 متميزه في وز }
\end{aligned}
$$

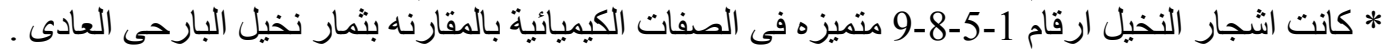

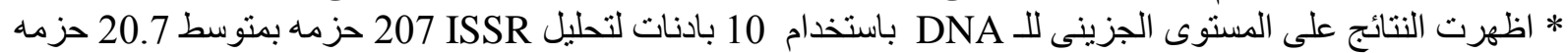

$$
\begin{aligned}
& \text { لكل بادئ - كان يتراوح الاختلاف بين } 76.9 \text { الى 100\% البادئ رقم } 7 \text { - } 8 \text { ـ سجلا اعلى نسبة اختلاف } 94.4 \text { - } \\
& .092 .9 \\
& \text { * كان التشابه الور اثى ضعيف جداً بين العثر سلالات تحت الدر اسه تراوحت بين } 11 \text { الى 64.1\% وكانت السلالتان رقم }
\end{aligned}
$$

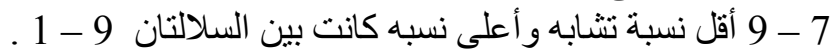

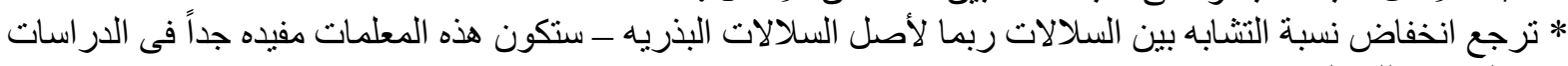

$$
\begin{aligned}
& \text { الور اثيه للنخيل مستقبلا . لخفيلة }
\end{aligned}
$$

المجلة العلمية لكلية الزراعة - جامعة القاهرة ـ المجلا (69) العدد الثالث (يوليو 2018):189- 199. 